\title{
Kelayakan Ruang Terbuka Hijau Publik Berdasarkan Karakteristik Fisik Ruang (Studi di Taman Kota Gajahwong, Kota Yogyakarta)
}

\author{
The Appropriateness of Public Green Open Space Based on Physical \\ Characteristics of Space (Study at Gajahwong City Park, Yogyakarta City)
}

\author{
Andi Sofie Febrina Salshabila ${ }^{\text {a*}}$, Annisa Mu'awanah Sukmawati ${ }^{\text {b }}$ \\ ${ }^{a, b}$ Program Studi Perencanaan Wilayah dan Kota, Fakultas Sains dan Teknologi, \\ Universitas Teknologi Yogyakarta, Yogyakarta, Indonesia
}

\begin{abstract}
Abstrak
Taman kota merupakan salah satu jenis ruang terbuka hijau publik. Studi berlokasi di Taman Kota Gajahwong Kota Yogyakarta yang mencakup tiga taman kota, yaitu Gajahwong Educational Park, Taman Wifi, dan Taman Krida. Taman Kota Gajahwong merupakan taman kota yang layak bagi Kota Yogyakarta karena keberadaan taman dan pola penggunaan lahan yang strategis. Namun, beberapa bagian taman nampak belum termanfaatkan optimal yang dilihat dari sepinya pengunjung taman. Penelitian bertujuan untuk menilai kelayakan taman kota berdasarkan karakteristik fisik di Taman Kota Gajahwong Kota Yogyakarta. Penelitian menggunakan pendekatan kuantitatif dengan teknik analisis deskriptif kuantitatif. Pengambilan sampel dilakukan dengan teknik Stratified Random Sampling dengan total sampel sebanyak 90 responden. Analisis menunjukkan bahwa Gajahwong Educational Park (GEP) merupakan model taman kota yang layak untuk dijadikan sebagai model ruang terbuka hijau publik yang baik berdasarkan variabel kemenarikan fisik taman, elemen pendukung, keberadaan vegetasi, dan aksesibilitas. Taman GEP menjadi taman yang paling layak dan menarik karena memiliki fasilitas yang lengkap, aksesibilitas yang baik, dan keragaman aktivitas yang bisa dilakukan di dalam taman.
\end{abstract}

Kata kunci: Karakteristik Fisik Ruang; Kota Yogyakarta; Taman Kota Gajahwong.

\begin{abstract}
City parks are one type of public green open space. The study is located in Gajahwong City Park, Yogyakarta City which includes three city parks, namely Gajahwong Educational Park, Wifi Park, and Krida Park. Gajahwong City Park is a suitable city park for the City of Yogyakarta because of the presence of parks and strategic land use patterns. However, some parts of the park appear to have not been optimally utilized as seen from the lack of visitors to the park. This study aims to assess the appropriateness of the park based on the physical characteristics of the space in Gajahwong City Park, Yogyakarta City. The research uses a quantitative approach with quantitative descriptive analysis techniques. Sampling was conducted by using the Stratified Random Sampling technique with a total sample of 90 respondents. The analysis shows that Gajahwong Educational Park (GEP) is a city park model that deserves to be used as a good public green open space model based on the physical attractiveness of the park, supporting elements, the presence of vegetation, and accessibility. GEP is the most feasible and attractive park because it has complete facilities, good accessibility, and a variety of activities that can be done in the park.
\end{abstract}

Keyword: Physical Characteristics of Space; Yogyakarta City; Gajahwong City Park.

\section{Pendahuluan}

Ruang terbuka publik (public open space) didefinisikan sebagai ruang yang terletak di luar massa bangunan yang dapat dimanfaatkan oleh siapa saja untuk melakukan berbagai kegiatan, serta memberikan kesempatan untuk melakukan bermacam-macam kegiatan.

\footnotetext{
* Corresponding author. Andi Sofie Febrina Salshabila

E-mail address: sofiefebsalshabila@gmail.com.
} 
Beberapa bentuk dari ruang terbuka publik meliputi jalan, pendestrian, taman lingkungan, plaza, lapangan olahraga, taman kota, dan taman rekreasi (Hakim, 2003). Definisi serupa juga disampaikan oleh Carr (1992), dimana ruang publik adalah ruang bersama yang dapat dimanfaatkan untuk melakukan berbagai aktivitas, baik aktivitas rutin maupun event-event pada waktu tertentu. Untuk itu, ruang terbuka publik dapat berfungsi sebagai ruang berinteraksi, bersantai/ berekreasi, pergerakan, dan titik pertemuan atau berfungsi untuk menunjang fungsi sosial, ekonomi, dan lingkungan/ ekologis.

Ruang publik dapat dikatakan berkualitas apabila memiliki beberapa kriteria kelayakan, yaitu kelayakan fungsional, visual, dan lingkungan (Danisworo, 1992). Lebih lanjut menurut Carr (1992), ruang publik agar dikatakan berkualitas memenuhi tiga komponen, yaitu aspek kebutuhan (responsive), hak (democratic), dan makna (meaningful). Kebutuhan artinya ruang publik harus dapat digunakan untuk beragam kegiatan dan kepentingan yang luas. Hak artinya ruang publik harus dapat digunakan oleh berbagai elemen masyarakat dari berbagai latar belakang, baik sosial, ekonomi, dan budaya. Sedangkan makna bahwa ruang publik memiliki makna bagi kehidupan perkotaan maupun masyarakat.

Dalam Peraturan Menteri Pekerjaan Umum Nomor 05/PRT/M/2008 tentang Pedoman Penyediaan dan Pemanfaatan Ruang Terbuka Hijau di Kawasan Perkotaan, ruang terbuka hijau didefinisikan sebagai area memanjang atau mengelompok yang bersifat terbuka, tempat tumbuh tanaman, baik yang tumbuh tanaman secara alamiah maupun yang sengaja ditanam. Jika dilihat dari kelayakan ruang terbuka hijau perumahan, luasan Ruang Terbuka Hijau (RTH) menurut Undang-undang No. 26 Tahun 2007 tentang Penataan Ruang ditetapkan bahwa RTH minimal memiliki luasan $30 \%$ dari luas total wilayah dengan proporsi $20 \%$ sebagai RTH publik. Demikian pula menurut Undang-undang Bangunan Gedung No. 28 Tahun 2002 yang mengatur tentang koefisien daerah hijau, RTH merupakan perangkat kendali utama bagi masyarakat atau swasta dalam membangun. Penyediaan RTH diatur pula dalam peraturan menteri PU No. 05/PRT/M/2008 tentang Pedoman Penyediaan dan Pemanfaatan RTH dan Keputusan Menteri Dalam Negeri No. 1 Tahun 2007 tentang Penataan RTH Kawasan Perkotaan. Sedangkan pengaturan rinci yang menyertai peraturan diatas tersebut, diantaranya tercantum pada SNI-031733-2004 tentang Tata Cara Perencanaan Lingkungan Perumahan Perkotaan yang menetapkan luasan minimum RTH lingkungan berdasarkan jumlah penduduk pendukung, kebutuhan luasan hijau per orang dan radius pencapaiannya.

Taman kota merupakan salah satu jenis dari ruang publik hijau publik. Dalam Peraturan Menteri Pekerjaan Umum No. 05/PRT/M/2008 tentang Pedoman Penyediaan dan Pemanfaatan Ruang Terbuka Hijau di Kawasan Perkotaan. Ruang Terbuka Hijau Publik (RTH Publik) dimaknai sebagai ruang terbuka hijau yang dimiliki dan dikelola oleh pemerintah setempat yang dimanfaatkan untuk kepentingan publik. Dalam pedoman tersebut juga diamanatkan bahwa proporsi RTH publik di wilayah perkotaan minimal 20\% dari total RTH.

Menurut Susiloarifin \& Nurhayati (1994), taman kota merupakan sebidang lahan yang ditata sedemikian rupa sehingga memiliki nilai keindahan, keamanan, dan keamanan bagi pemiliknya maupun penggunaannya. Merujuk pada hal tersebut, maka taman kota sebagai RTH publik memiliki peran penting bagi sebuah kota karena merupakan ruang milik bersama yang dapat digunakan untuk melakukan berbagai aktivitas, baik bersantai, berinteraksi sosial, maupun untuk fungsi ekologis. Menurut Harjanti \& Anggraini (2020) bahwa RTH publik maupun privat bermanfaat bagi kualitas hidup masyarakat dan lingkungan karena menyangkut fungsi ekologi, estetik, dan ekonomi. Serupa menurut Mashuri et al. (2012), RTH publik berupa taman kota dan hutan kota memiliki fungsi estetika sebab efek visual taman yang indah sehingga berdampak bagi psikologis sesesorang. Selain itu, juga berfungsi sebagai paru-paru kota, pengendali iklim mikro, konservasi air, dan habitat bagi berbagai tumbuhan dan hewan sehingga menimbulkan kesan nyaman bagi penggunanya. Ini menunjukkan bahwa bagi wilayah perkotaan keberadaan RTH publik akan bermanfaat untuk meningkatkan kualitas hidup masyarakat perkotaan, produktivitas masyarakat, dan membantu terciptanya perkotaan yang berkelanjutan.

Beberapa studi menunjukkan bahwa ada keterkaitan antara tatanan fisik ruang dengan kelayakan penggunaan ruang terbuka hijau publik, khusunya pada taman kota. Ruang terbuka hijau publik yang nyaman adalah RTH yang memiliki fasilitas penunjang yang memadai baik untuk menunjang fungsi kebersihan dan keamanan, seperti fasilitas tempat duduk, kebersihan, dan ruang bermain anak (Shakia et al., 2020). Penelitian Bandaso \& Widjajanti (2019) juga menemukan bahwa kondisi fisik taman kota berupa keberadaan jalur pedestrian dan parkir akan 
meningkatkan kenyamanan pengunjung. Begitu juga penelitian Imansari \& Khadiyanta (2015) bahwa taman kota dapat memberikan kenyamanan dan meningkatkan vitalitas kawasan ketika dapat menyediakan fasilitas yang memadai, seperti penjual kuliner. Studi pada taman kota di Kota Surakarta oleh Pratomo et al. (2019) juga menunjukkan bahwa keberadaan elemen pendukung, meliputi fasilitas kebersihan, seperti toilet dan wastafel, tempat duduk, tempat sampah, papan pengumuman, lampu taman, dan tempat bermain anak dapat meningkatkan kualitas taman. Lebih lanjut, Hariyadi et al. (2015) menambahkan bahwa selain ketersediaan fasilitas, keberadaan vegetasi juga turut mempengaruhi kualitas fisik taman kota. Ini karena keberadaan taman kota juga perlu untuk menunjang fungsi ekologis, selain dari fungsi estetika, sosial, dan ekonomi. Dari penelitian-penelitian tersebut dapat dikatakan bahwa RTH publik yang layak dapat dilihat dari keberadaan fasilitas penunjang serta keberadaan vegetasi hijau di dalam atau sekitar taman yang bermanfaat untuk meningkatkan kualitas taman, baik dari segi estetika dan keberfungsiannya sehingga nyaman digunakan oleh pengunjung.

Taman Kota Gajahwong adalah salah satu taman kota yang berada di tengah Kota Yogyakarta. Taman Kota Gajahwong berlokasi di RT 45, RW 08 Kampung Gambiran, Kota Yogyakarta. Taman kota tersebut merupakan salah satu taman kota yang baik dan layak di Kota Yogyakarta baik dari karakteristik fisik, pola penggunaan lahannya, serta kenyamanan bagi penggunanya karena terkelola dengan baik serta memiliki sarana prasarana taman yang memadai (Dinas Lingkungan Hidup Kota Yogyakarta, 2019). Taman Kota Gajahwong ditata dan dikelola dengan baik oleh warga sekitar dengan dukungan Pemerintah Kota Yogyakarta. Menurut Mandagi (2013), taman kota perlu dibangun secara tematik yang pembangunannya merefleksikan karakteristik, potensi wilayah, kemampuan ekonomi, dan budaya lokal. Begitu pula dengan Taman Kota Gajahwong yang pembangunannya memiliki fungsi untuk memenuhi fungsi ekologis, sosial, dan budaya masyarakat setempat serta untuk mendukung pengembangan Kota Yogyakarta sebagai kota hijau (green city).

Meskipun Taman Kota Gajahwong dikategorikan sebagai taman yang baik dan layak karena memiliki beragam fasilitas yang memadai, berdasarkan hasil pengamatan peneliti di lapangan keberadaannya belum cukup maksimal termanfaatkan sebagai ruang aktivitas masyarakat setempat. Kondisi ini diperkuat oleh hasil penelitian Setyaningrum \& Susanti (2019) pada sebagai RTH publik aktif, taman tersebut minim pengunjung dan rawan akan kriminalitas karena sepinya kondisi taman. Selain itu, keberadaan sarana dan prasana kurang termanfaatkan optimal sehingga keberadaan taman terkesan mubazir. Padahal keberadaannya dikelilingi oleh permukiman. Keberadaan taman menjadi salah satu taman kota juga direncanakan dengan baik oleh masyarakat setempat, tetapi kurang digunakan oleh pengunjung luar. Padahal, keberadaan taman kota sangat penting bagi sebuah kota. Selain untuk menunjang fungsi ekologi juga berfungsi sebagai ruang publik, yaitu untuk berinteraksi bagi masyarakat perkotaan ditengah kesibukan aktivitasnya.

Penelitian ini mencakup 3 taman yang berada di Kawasan Taman Kota Gajahwong, yaitu Gajahwong Educational Park (GEP), Taman Krida, dan Taman Wifi. Jika dilihat dari fungsinya, Gajahwong Educational Park memiliki fasilitas utama berupa jogging track dan playground area untuk anak-anak. Taman Krida memiliki fasilitas penunjang utama sarana olahraga yang meliputi lapangan tenis dan outdoor. Sementara itu, Taman Wifi, merupakan taman yang bertema teknologi dengan menyediakan jaringan wifi gratis. Gambar 1 adalah peta kawasan penelitian dengan tiga taman yang terdapat di dalamnya (Taman GEP, Taman Wifi, dan Taman Krida).

Secara administratif, Taman Kota Gajahwong berada di Kecamatan Umbulharjo, Kelurahan Pandeyan, Kota Yogyakarta dan memiliki luas lahan $5.000 \mathrm{~m}^{2}$. Pengembangan Taman Kota Gajahwong dilakukan oleh masyarakat setempat, Pemerintah Kota Yogyakarta beserta instansi terkait. Pembangunannya dilatarbelakangi oleh upaya pemenuhan standar minimal persyaratan ketersediaan Ruang Terbuka Hijau (RTH) melalui pembangunan fisik. Secara lokasi, Taman Kota Gajahwong terletak di daerah pinggiran Kota Yogyakarta yang sebagian wilayahnya merupakan daerah permukiman dan perkantoran. 


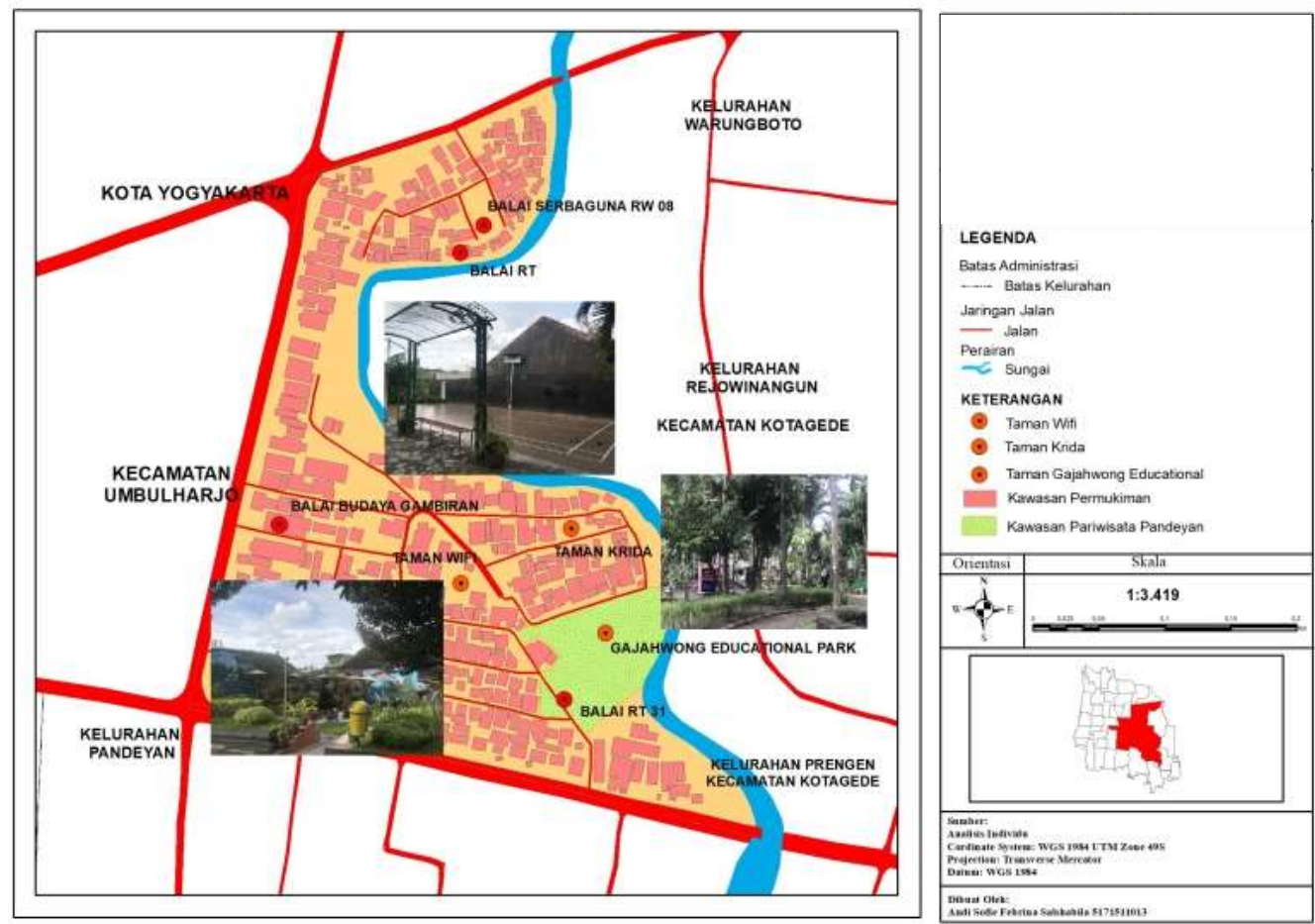

Gambar 1. Peta Lokasi Penelitian (Peneliti, 2021)

Penelitian sebelumnya pada RTH publik di Kampung Hijau Gambiran (lokasi di Taman GEP dan Taman Krida) oleh Setyaningrum \& Susanti (2019) menunjukkan bahwa ketersediaan fasilitas dan vegetasi, aspek lokasi, aksesibilitas, serta kemampuan taman untuk menampung beragam aktivitas masyarakat menjadikan RTH memiliki daya tarik. Taman GEP dianggap sebagai RTH publik yang paling menarik karena memiliki fasilitas yang lengkap, vegetasi yang baik, serta desain dan fungsi taman yang baik. Sedangkan Taman Krida dianggap paling tidak menarik karena faktor lokasi kurang strategis. Hal ini menunjukkan bahwa ada persepsi pengunjung yang menentukan bagaimana sebuah taman akan digunakan salah satunya dilihat dari karakteristik fisik taman tersebut. Menggali persepsi pengguna taman kota menjadi salah satu cara mengetahui kelayakan dan kualitas fisik taman yang dimiliki. Nasution \& Zahrah (2014) menyatakan bahwa ada korelasi antara persepsi pengunjung untuk menggunakan ruang terbuka publik dengan peningkatan kualitas hidup mereka terkait dengan aspek kesehatan dan fungsi ruang.

Berdasarkan latar belakang tersebut muncul rumusan masalah, yaitu "bagaimana kelayakan Taman Kota Gajahwong berdasarkan karakteristik fisiknya?". Untuk itu, tujuan dari penelitian untuk menilai kelayakan taman kota berdasarkan karakteristik fisik ruang di Taman Kota Gajahwong. Penelitian diharapkan dapat menjadi masukkan bagi pemerintah untuk mengembangkan taman-taman kota dengan melihat persepsi masyarakat terhadap kriteria taman kota yang layak dan tepat. Oleh sebab itu, peneliti ingin menggali mengenai daya tarik taman dengan menjelaskan karakteristik dan kualitas taman kota yang layak. Pada akhirnya menentukan tingkat kelayakan suatu taman dinilai dengan melihat aspek fasilitas di dalamnya. Adapun perbedaan dengan penelitian Setyaningrum \& Susanti (2019) tersebut adalah terkait perihal cakupan lokasi penelitian, dimana dalam penelitian ini peneliti mengambil tiga taman sebagai lokasi studi, yaitu Taman GEP, Taman Krida, dan Taman Wifi yang sama-sama berada di kawasan Taman Kota Gajahwong di Kampung Gambiran.

\section{Metode}

Penelitian menggunakan metode penelitian kuantitatif. Penelitian kuantitatif dipilih karena peneliti akan melakukan penilaian terhadap tingkat kelayakan taman kota dengan menggunakan beberapa variabel terpilih. Metode pengumpulan data yang digunakan adalah metode pengumpulan data primer dan sekunder. Data primer yang digunakan berupa data hasil kuesioner kepada masyarakat yang bertempat tinggal di sekitar Taman Kota Gajahwong, yaitu 
warga RW 08 RT 30, 31, 32, 45, dan 47 Taman Kota Gajahwong, Kelurahan Pandeyan, Kecamatan Umbulharjo, Kota Yogyakarta dengan total 792 orang. Pengumpulan sampel dilakukan dengan menggunakan teknik Stratified Random Sampling kepada 90 orang. Selain itu, data primer juga diperoleh melalui observasi yang dilakukan langsung oleh peneliti untuk mengamati karakteristik fisik taman kota, seperti ketersediaan fasilitas, aksesibilitas, dan aktivitas yang dilakukan di taman kota. Sedangkan data sekunder dikumpulkan melalui telaah dokumen hasil survey instansi ke Dinas Lingkungan Hidup Kota Yogyakarta dan kantor Kelurahan Pandeyan. Data primer dan data sekunder dikumpulkan pada saat penelitian, kemudian dianalisis untuk memperoleh gambaran mengenai tingkat kelayakan taman kota berdasarkan karakteristik ruang di Taman Kota Gajahwong.

Analisis dilakukan dengan teknik analisis deskriptif kuantitatif yang dijelaskan dengan menggunakan persentase hasil olahan kuesioner serta deskripsi penjelas. Variabel yang dianalisis meliputi kemenarikan kondisi fisik taman, elemen/ infrastruktur pendukung, elemen vegetasi, dan aksesibilitas. Kemenarikan fisik taman dianalisis berdasarkan kondisi kebersihan, keberadaan vegetasi hijau, dan keberadaan fasilitas di dalam taman, seperti tempat bermain anak, area jogging track, luas taman, desain taman, tempat duduk, gazebo, dan lainnya. Variabel elemen/ infrastruktur pendukung dianalisis dengan menggunakan indikator keberadaan peta/ denah taman untuk memudahkan pengunjung mendapat informasi mengenai taman. Elemen vegetasi dianalisis berdasarkan indikator kondisi (kerimbunan) vegetasi dan penataan vegetasi. Variabel aksesibilitas dianalisis dengan indikator keberadaan area parkir, petunjuk arah, dan kondisi perkerasan jalan.

\section{Hasil dan Pembahasan}

\subsection{Gambaran Umum Taman Kota Gajahwong}

Lingkup materi penelitian ini terbagi menjadi tiga ruang publik yaitu Taman Gajahwong Educational Park (GEP), Taman Wifi, dan Taman Krida. Adapun deskripsi kondisi masingmasing taman sebagai berikut.

1) Gajahwong Educational Park adalah taman tematik yang memiliki penekanan pada fungsi edukasi. Taman GEP memiliki kondisi taman yang bersih, ketersediaan permainan untuk bermain anak-anak, luas taman yang baik, desain taman yang menarik, ketersedian fasilitas yang cukup lengkap, serta banyaknya vegetasi hijau. Taman ini memiliki ketersedian fasilitas utama berupa playground area dan jogging track sesuai dengan temanya bahwa educational park merupakan tempat yang tidak hanya sekedar untuk bersantai atau sekedar berinteraksi sosial namun juga memiliki fungsi edukasi, utamanya bagi anak-anak. Gambar 2 berikut ini adalah gambar lokasi Taman Gajahwong Educational Park.

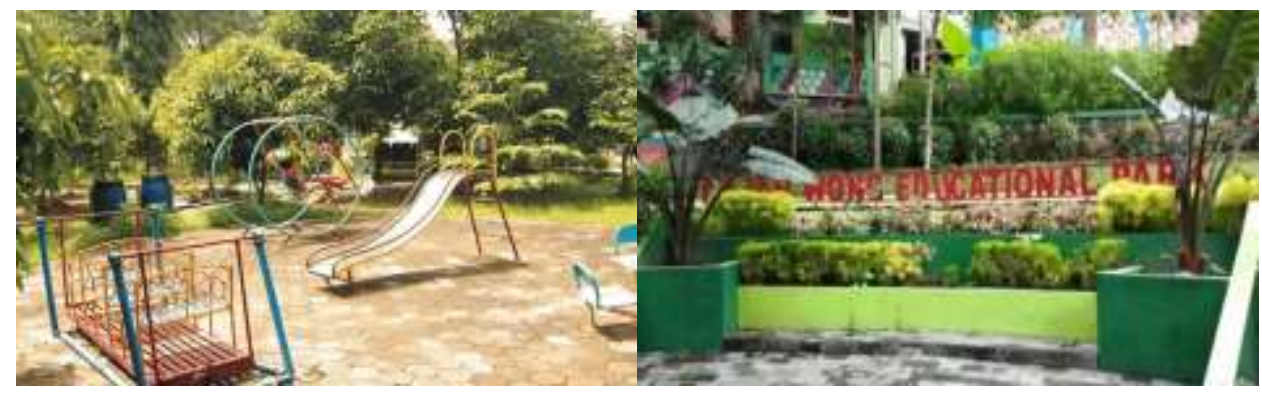

Gambar 2. Kondisi Taman Gajahwong Educational Park (Dokumentasi Peneliti, 2021)

2) Taman Wifi adalah taman yang didirikan oleh Pemerintah Kota Yogyakarta di tahun 2019, masih berlokasi satu kawasan dengan Taman Kota Gajahwing. Taman Wifi ini menyediakan fasilitas internet gratis bagi pengunjung taman sejalan dengan program pemerintah untuk mewujudkan Jogja Smart City (Dinas Lingkungan Hidup Kota Yogyakarta, 2019). Taman ini memiliki fasilitas yang cukup menjadi daya tarik ruang publik karena ketersediaan fasilitas dan balai taman, kemampuan dalam menampung aktivitas masyarakat, serta lokasi dan aksesibilitas dari taman tersebut. Taman wifi juga 
cukup menarik karena memiliki desain yang menarik, yaitu kolam ikan, vegetasi taman, air terjun mini, dan kursi taman. Gambar 3 berikut ini gambar dari Taman Wifi.

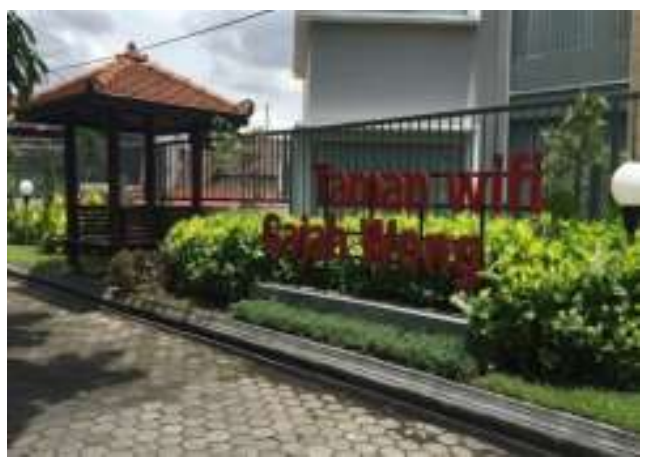

Gambar 3. Kondisi Taman Wifi (Dokumentasi Peneliti, 2021)

3) Taman Krida memiliki luas $238 \mathrm{~m}^{2}$ dengan fasilitas utama lapangan tenis dan fitness outdoor. Fasilitas pendukung Taman Krida yang tersedia meliputi satu gazebo, satu tempat duduk panjang, satu tempat sampah, satu lampu penerangan, dan belum adanya petunjuk arah. Hal tersebut mengakibatkan tidak banyak masyarakat luar sekitar kawasan Taman kota Gajahwong yang tahu mengenai keberadaan taman ini. Gambar 4 berikut ini menggambarkan kondisi Taman Krida.

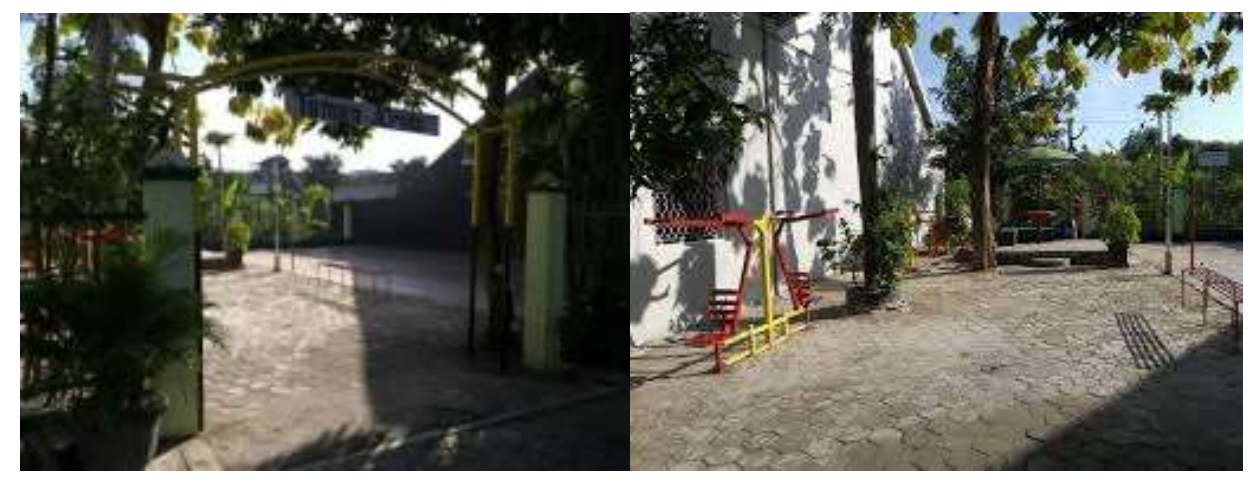

Gambar 4. Kondisi Taman Krida (Dokumentasi Peneliti, 2021)

\subsection{Analisis Karakteristik Fisik di Taman Kota Gajahwong}

Menurut Peraturan Walikota Yogyakarta Nomor 5 Tahun 2016 Tentang Ruang Terbuka Hijau Publik sebagaimana dimaksud dalam bab 2 pasal 5 mengenai Pengadaan RTH publik bahwa ruang publik diperoleh dari ahli fungsi lahan milik Pemerintah Daerah dan pengadaan tanah oleh Pemerintah Daerah yang khusus diperuntukan menjadi RTH publik. Peraturan tersebut mempengaruhi pada penentuan karakteristik fisik ruang publik yang layak untuk taman kota. Menurut Lynch (1960), ciri-ciri fisik dan penampilan berperan penting dalam mempengaruhi pencitraan tempat. Hal tersebut berkontribusi untuk membuat tempat lebih mudah dibaca oleh pengguna dengan identifikasi tata letak dan kejelasan cityspace dalam bentuk fisik dan fungsinya.

\subsubsection{Kondisi Kemenarikan Fisik Taman}

Berdasarkan hasil kuesioner kepada 99 responden, didapatkan bahwa RTH yang paling menarik adalah Gajahwong Educational Park (54\%). RTH yang paling menarik kedua, yaitu Taman Wifi (36\%), dan pada urutan terakhir, yaitu Taman Krida (10\%). Persepsi responden mengenai masing-masing taman berdasarkan kemenarikannya dapat dilihat pada gambar 5 . 


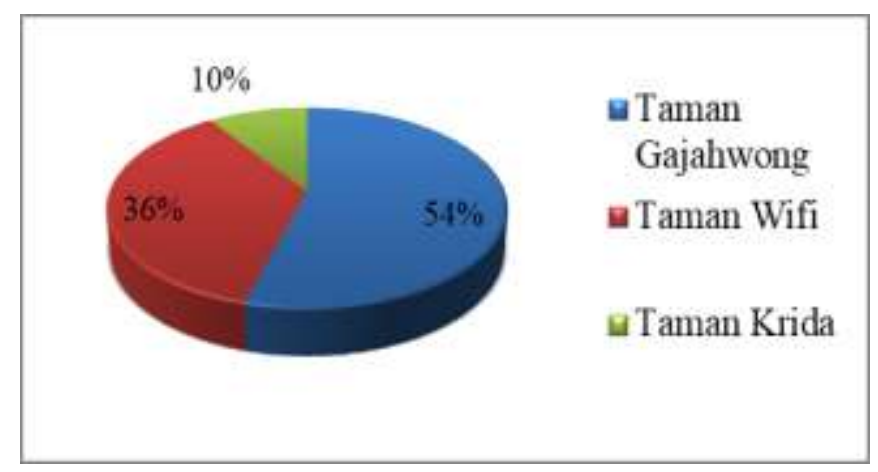

Gambar 5. Persepsi Responden Mengenai Kemenarikan RTH Publik Taman Kota Gajahwong (Analisis Peneliti, 2021)

Mayoritas responden berpendapat bahwa menariknya Taman Gajahwong Educational Park (GEP) karena kondisi taman yang bersih, ketersediaan fasilitas permainan untuk anakanak, luas taman yang cukup besar, desain taman yang menarik, ketersediaan fasilitas yang cukup lengkap, serta banyaknya vegetasi hijau. Taman GEP juga memiliki playground area dan jogging track yang menjadi daya tarik tersendiri bagi pengunjungnya, serta area edukasi bagi pengunjung terutama anak-anak. Taman GEP dapat menjadi tempat dimana masyarakat dapat menggunakan fasilitas-fasilitas yang rekreatif dan edukatif. Fasilitas rekreatif dan edukatif lainnya yang tersedia di Taman GEP, yaitu papan pengetahuan seperti sejarah Kota Yogyakarta, papan pengetahuan terkait tanaman dan hewan serta adanya interaksi langsung terhadap flora dan fauna yang ada. Gambar 6 menggambarkan suasana di Gajahwong Educational Park.

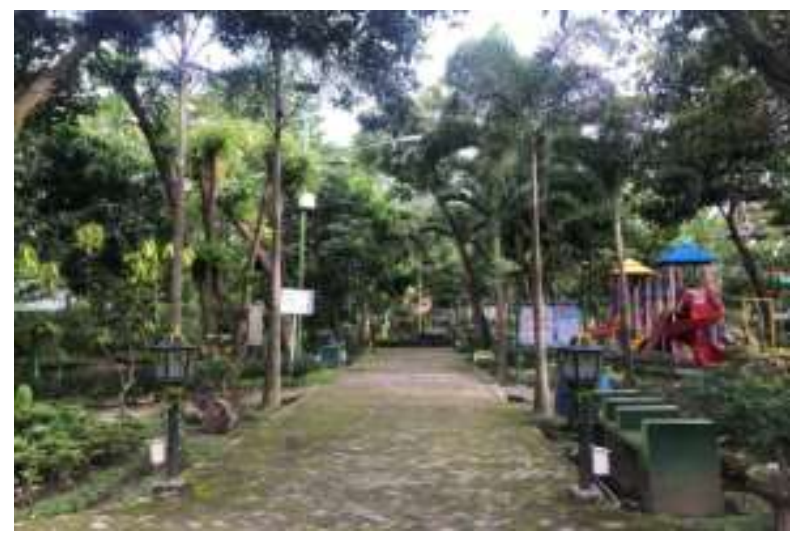

Gambar 6. Suasana di Taman GEP yang Menarik Minat Pengunjung (Dokumentasi Peneliti, 2021)

Sebanyak $86 \%$ responden menjawab bahwa untuk tingkat kenyamanan pengunjung dari karakteristik kebisingan dan kondisi taman yang terpengaruh oleh iklim, serangga, maupun kelompok tertentu sudah efektif. Untuk tingkat gangguan iklim terkadang karena fasilitas gazebo yang terdapat di taman saat ini banyak yang tidak layak digunakan, jika hujan dan angin kencang pengunjung yang berteduh di gazebo tersebut terkadang terkena percikan air. Untuk gangguan serangga, pengunjung terkadang terganggu oleh serangga nyamuk karena banyak pohon yang rimbun karena masyarakat yang kurang sadar untuk memangkas pohon dan kolamkolam yang tidak terpakai.

Gajahwong Educational Park memiliki kondisi yang bersih dan jarang ditemukan sampah, tanaman yang ada juga tumbuh terawat. Kondisi taman yang luas merupakan salah satu kriteria RTH publik yang baik karena memungkinkan untuk melakukan banyak kegiatan di dalamnya. Bersihnya taman dan tanaman yang terawat dikarenakan taman tersebut dikelola oleh DLH Kota Yogyakarta dan kontribusi masyarakat yang turut berpartisipasi. Banyaknya vegetasi di Taman GEP sesuai dengan fungsi taman sebagai paru-paru kota.

Taman Krida menjadi taman yang dianggap paling tidak menarik menurut pengunjung. Meskipun memiliki fasilitas pendukung seperti gazebo, satu tempat duduk panjang, satu tempat sampah, satu lampu penerangan, namun taman ini juga memiliki kekurangan seperti belum adanya petunjuk arah. Hal tersebut mengakibatkan tidak banyak masyarakat luar yang tahu akan 
keberadaan taman. Kondisi tersebut juga kurang sesuai dengan teori bahwa RTH publik yang baik yaitu terdapatnya informasi yang jelas tentang tempat tersebut bahwa tersedia untuk digunakan. Suasana Taman Krida terlihat pada Gambar 7.

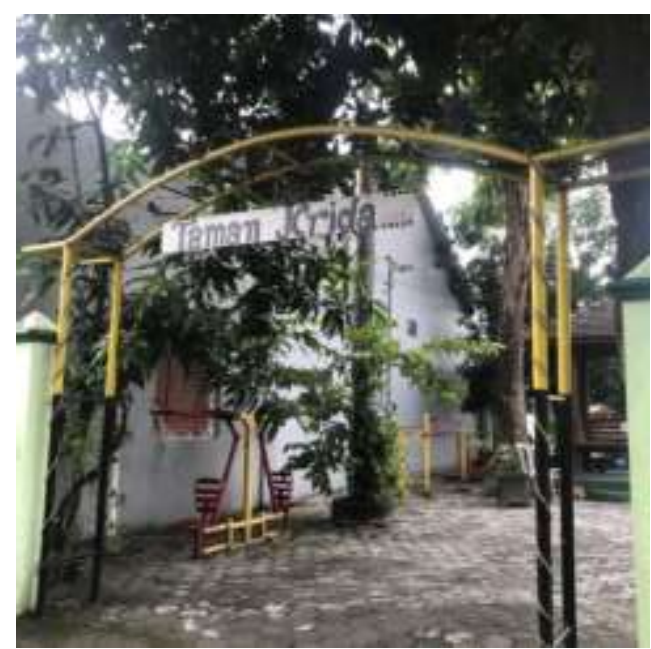

Gambar 7. Suasana di Taman Krida yang Minim Fasilitas dan Aksesibilitas yang Kurang Terjangkau (Dokumentasi Peneliti, 2021)

Responden mengaku banyak yang tidak mengetahui dan mengaku belum pernah berkunjung ke Taman Krida karena kurangnya sosialisasi. Masyarakat yang tahu akan Taman Krida juga jarang menggunakannya. Salah satu alasan karena lokasi taman yang dianggap kurang strategis. Lokasi Taman Krida berada di dalam gang dimana jalan di gang tersebut hanya dilalui pengendara motor. Hal tersebut juga kurang sejalan dengan teori bahwa salah satu RTH publik yang baik, yaitu memiliki lokasi yang mudah diakses. Adapun hasil kuesioner terhadap responden mengenai alasan ketidakmenarikan Taman Krida dibandingkan kedua taman lainnya, dapat dikelompokkan menjadi beberapa kategori seperti pada grafik di gambar 8 berikut.

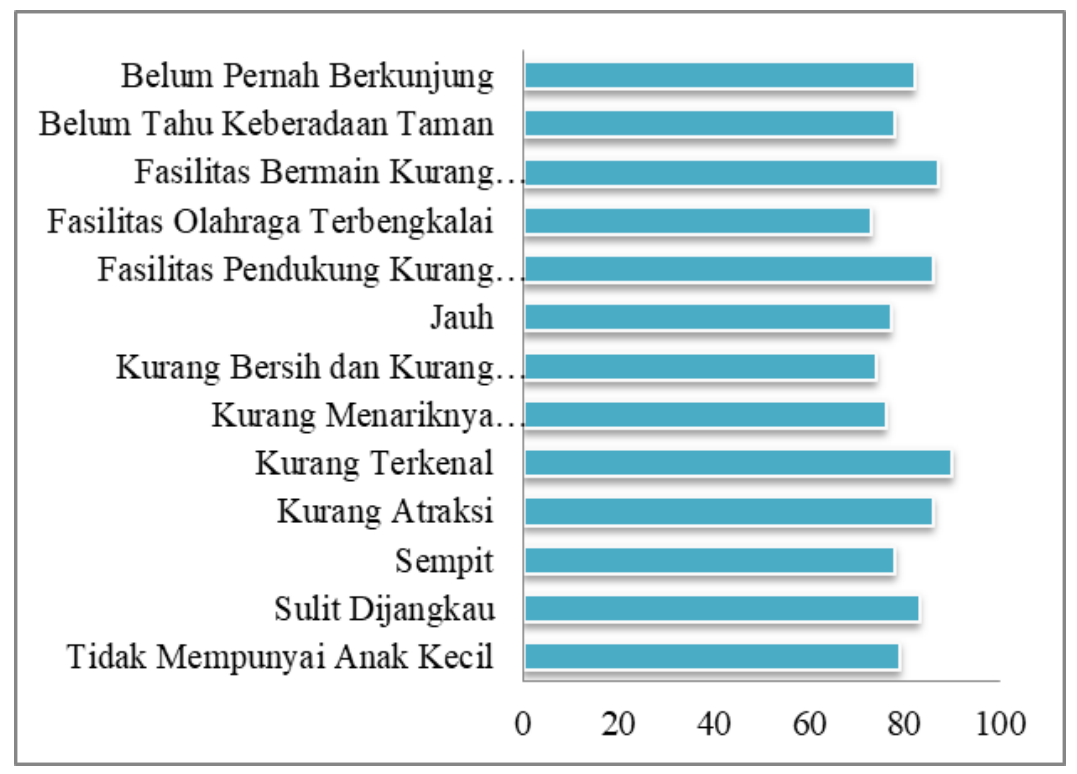

Gambar 8. Beberapa Alasan Mengenai Kondisi RTH Publik yang Tidak Menarik (Analisis Peneliti, 2021)

Adapun beberapa alasan yang menjadikan Taman GEP Park dinilai menarik dibandingkan kedua taman lainnya karena adanya beberapa alasan. Alasan-alasan yang menjadikan RTH publik menarik tersebut dikelompokkan menjadi beberapa kategori seperti yang dapat dilihat pada gambar 9 berikut. 


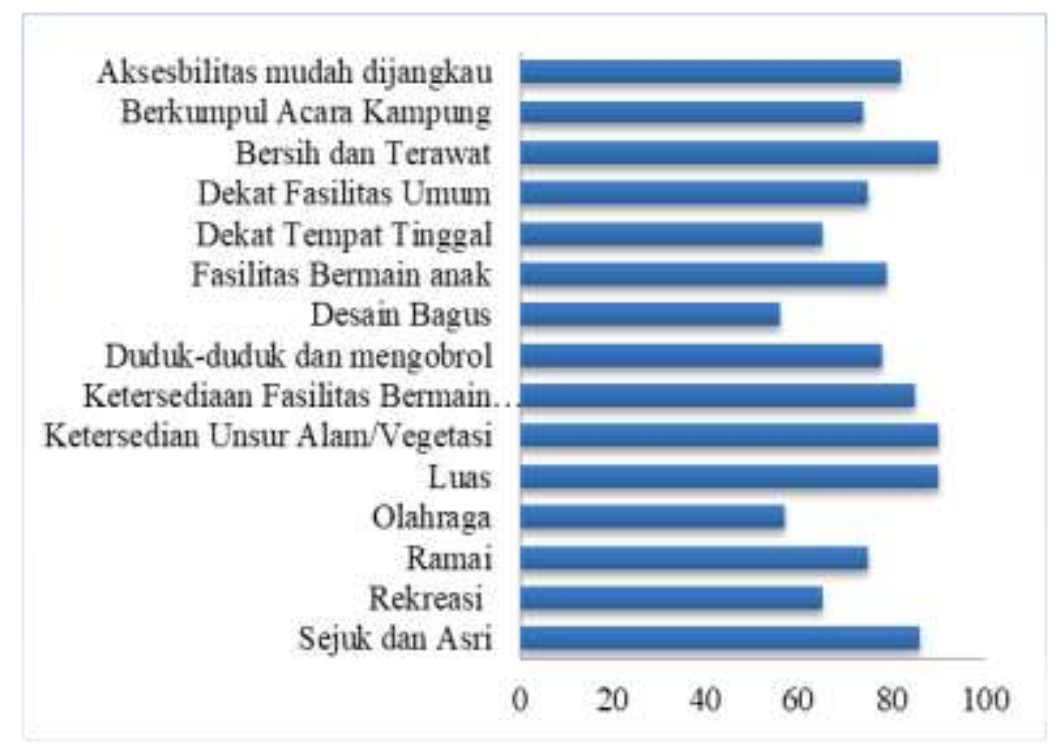

Gambar 9. Beberapa Alasan Mengenai Kondisi RTH Publik yang Menarik (Analisis Peneliti, 2021)

Kehadiran ruang terbuka publik sangat penting untuk menunjang kualitas lingkungan dan juga merupakan sarana pembentuk untuk menunjang kualitas lingkungan dan juga merupakan sarana pembentuk serta membina mental masyarakat dengan keberadaan ruang terbuka publik pada lingkungan perumahan. Meskipun hanya sebagai fasilitas penunjang, ruang terbuka publik menjadi bagian penting. Oleh sebab itu, dari hasil hasil kuesioner kepada masyarakat maupun pengunjung Taman Kota Gajahwong menunjukkan bahwa $60 \%$ dari total 80 responden memilih bahwa dengan adanya Taman Kota Gajahwong pada lingkungan perumahan ini sangat layak dan menunjang aktivitas perkotaan dan untuk 35\% dari jumlah total 10 responden memilih kurang layaknya dengan keberadaan Taman Kota Gajahwong.

\subsubsection{Elemen Pendukung/Infrastruktur Taman}

Karakteristik fisik taman terbentuk dari elemen buatan meliputi unsur bangunan taman, infastruktur taman, furniture taman dan fasilitas taman (Budiyanti, 2013). Adanya infastruktur taman, seperti tata tertib yang dapat memudahkan pengunjung menaati peraturan berkunjung di taman. Selain itu, peta taman (masterplan) yang dapat memudahkan pengunjung mengakses taman dan mengetahui lokasi elemen taman lainnya. Papan informasi juga merupakan elemen sangat penting bagi taman agar pengunjung tidak tersesat dan mudah mengakses tujuannya. Pada fasilitas papan informasi dilihat dari segi penunjuk arah dari depan jalan hingga akses menuju taman.

Responden hasil kuesioner mengatakan dengan ada pertambahannya beberapa papan informasi di pinggiran jalan sudah cukup akurat bagi pengunjung mengakses taman, tetapi $23 \%$ masyarakat dan pengunjung taman mengatakan untuk papan informasi taman dikatakan kurang akurat, karena dengan penunjuk arah yang kurat jelas mengakibatkan pengunjung sering kali tersesat. Pada fasilitas tata tertib, Masyarakat maupun pengunjung taman cukup memahami tata tertib yang tersedia. Untuk 15 responden mengatakan tidak melihat sama sekali tersedianya tata tertib taman dan rata-rata $17 \%$ responden mengatakan bahwa tata tertib taman kurang spesifik, seharusnya dibuat dalam 1 kategori agar pengunjung tidak malas untuk membaca. Lebih lanjut, rekapan kuesioner menunjukkan bahwa 49 responden dari total 90 responden milih "YA" untuk elemen Peta Taman (Masterplan) dalam mengakses taman sudah efektif. Sedangkan untuk 31 responden mengatakan tidak sama sekali melihat adanya peta taman, peta taman sudah tidak jelas, peta taman sudah tidak layak dan kurang memahami simbol-simbol di dalam peta taman tersebut. Adapun gambar papan informasi di Taman Kota Gajahwong terlihat di Gambar 10. 

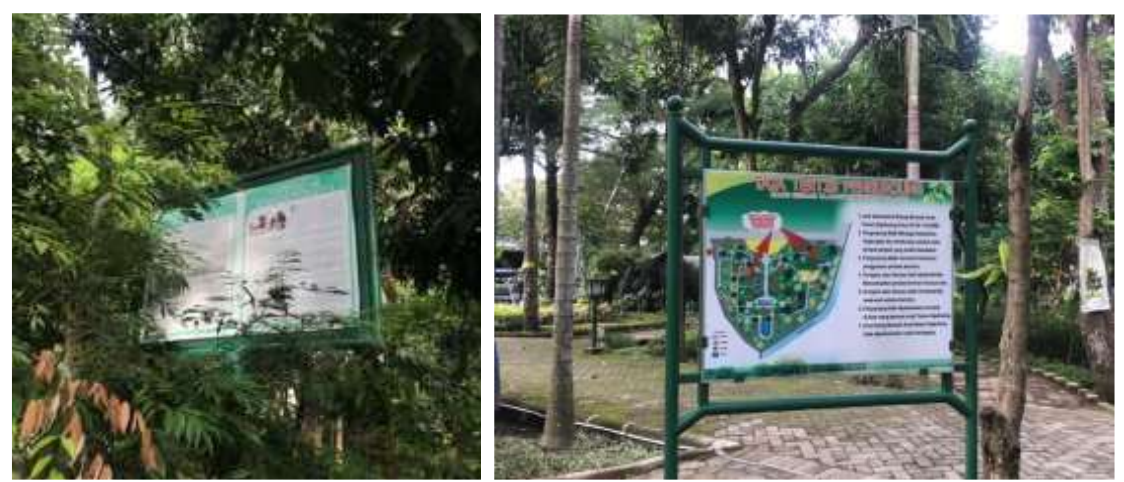

Gambar 10. Papan Informasi di Taman Kota Gajahwong (Dokumentasi Peneliti, 2021)

\subsubsection{Penataan Vegetasi}

Dari observasi yang dilakukan, vegetasi yang rimbun menghasilkan ruang yang cenderung gelap dari pada vegetasi yang jarang, maka vegetasi yang rimbun dapat menurunkan persepsi keamanan. Namun di sisi lain, dalam fisik ruang melakukan penataan vegetasi sangat berpotensi positif dalam bentuk lingkungan dan membuat keasrian pada taman. Sebanyak $61 \%$ responden menyatakan bahwa tidak ada kegiatan rutin yang dilakukan masyarakat setiap minggunya dalam penataan vegetasi. Oleh sebab itu, penataan vegetasi pada Taman Kota Gajahwong belum baik. Ini karena pada saat ini perkumpulan pada Taman Kota Gajahwong dibatasi karena pandemi Covid-19. Hanya ada satu stakeholder yang membantu penataan vegetasi taman, yaitu dari pihak Dinas Lingkungan Hidup (DLH) Kota Yogyakarta. Akan tetapi masyarakat berupaya membantu melakukan penataan vegetasi di lingkungan sekitar permukiman. Hal ini karena akan memperindah lingkungan sekitar taman, keasrian lingkungan, kenyamanan, dan berpengaruh positif untuk daya tarik pengunjung sendiri.

Sebanyak 93\% responden menyatakan bahwa tingkat kebersihan pada lingkungan taman sudah baik. Ini karena masyarakat maupun Dinas Lingkungan Hidup (DLH) Kota Yogyakarta setiap harinya membersihkan lingkungan taman. Untuk masyarakat membantu berpartisipasi membersihkan di lingkungan perumahan masing-masing. Sedangkan untuk DLH sendiri membersihkan di bagian tamannya. Dari hasil observasi lapangan dapat dilihat bahwa untuk kebersihan tamannya bebas dari sampah plastik lainnya. Hanya terdapat beberapa sampah perpohonan. Dari Dinas Lingkungan Hidup (DLH) sendiri melakukan pengelolaan dengan mendaur kembali sampah perpohonan maupun sampah plastik dari Taman Kota Gajahwong.

\subsubsection{Aksesibilitas}

Akses merupakan prasyarat penting dalam menentukan kualitas suatu ruang publik. Menurut Lynch (1960), terdapat 3 jenis akses penting di ruang publik, yaitu akses fisik langsung dengan keberadaan pintu masuk ke sebuah tempat, akses sosial atau ruang untuk kelas dan jenis pengguna yang berbeda, dan akses visual, yaitu kemampuan untuk melihat ke ruang publik yang dituju. Tempat yang terbaca akan memungkinkan orang untuk memiliki gambaran yang jelas dan akurat sehingga masyarakat dapat menggunakannya sesuai dengan kebutuhan mereka. Lebih lanjut, Shirvani (1985) menjelaskan komponen aksesibilitas dalam elemen fisik perancangan ruang kota terdiri dari sistem penghubung, ruang terbuka pendukung aktivitas, penggunaan block jalan dan sistem penanda.

Area parkir berfungsi untuk menunjang fungsi sirkulasi/ pergerakan. Area ini perlu didukung oleh sebaran kantung parkir. Dengan ketersediaan lahan kantung parkir, penggunaan jalan sebagai sirkulasi dan parkir kendaraan akan seimbang dengan penggunaannya sebagai ruang sosial. Hasil observasi menunjukkan bahwa ketersediaan area parkir pengunjung hanya terdapat pada Taman Gajahwong Educational Park karena dengan luasan penggunaan lahan yang cukup untuk ketersediaan lahan parkir mobil dan motor.

Ditinjau berdasarkan aspek topografi, elemen pendukung lain dari ketersediaan ruang publik yaitu tingkat kondisi perkerasan jalan. Pada Taman Kota Gajahwong, perkerasan jalan berupa paving blok. Pengembangan ruang publik kawasan perkotaan sebelumnya telah diinisiasi oleh pemerintah dan masyarakat yang turut berpartisipasi, berupa pembangunan sarana dan 
prasarana seperti pembetonan jalan setapak. Terbentuknya ruang publik sendiri dilihat dari pola grid bangunan jalan dan bentuk koridor ruang publik. Sementara itu, jika dilihat dari tingkat kelebaran dan keselamatan jalan, sebanyak $87 \%$ menyatakan bahwa untuk tingkat kelebaran dan keselamatan jalan pada lingkungan Taman Kota Gajahwong sudah baik karena jalan dilalui dua arah dengan lebar jalan sekitar 7,98 meter serta dapat dilalui pengendara mobil dan pengendara sepeda motor. Untuk tingkat keselamatan pejalan kaki sudah cukup baik untuk dilalui karena kondisi ruang yang cenderung sepi sehingga tidak begitu menganggu untuk pejalan kaki. Sedangkan $12 \%$ responden sisanya menyatakan tingkat keselamatan jalan kurang baik karena jalan yang berada di dekat Taman Wifi hanya bisa dilalui searah saja, kondisi jalan menuju taman cukup curam pada saat turunan, dan jalan naik dari Taman GEP yang dekat dengan dengan mushola sehingga menuju jalan keluar cukup tinggi.

Sebanyak 93\% responden menjawab bahwa tingkat keamanan pada Taman Kota Gajahwong sudah baik. Ini karena dari tingkat penggunaan lahan taman yang aman dari lalu lintas dan tidak begitu berisik. Hanya suara kendaraan yang melintas di lingkungan taman yang kadang terdengar cukup berisik, karena kondisi jalan menuju taman cukup curam. Masyarakat Taman Kota Gajahwong telah berupaya mengoptimalkan tingkat keamanan lingkungannya melalui ronda keliling taman. Kegiatan ini juga sudah didukung oleh keberadaan pos ronda sebagai tempat berkumpul petugas keamanan.

Jika dilihat dari fasilitas petunjuk arah, sebanyak 58\% responden menyatakan bahwa fasilitas petunjuk arah menuju taman sudah baik, dimana akses awal sebelum menuju taman terdapat beberapa petunjuk arah. Fasilitas petunjuk arah sudah cukup lengkap menuju beberapa titik lokasi, seperti petunjuk mushola, balai RT, perpustakaan, Taman Gajahwong Educational Park, toilet, dan jalur evakuasi. Petunjuk arah tersebut membantu para pengunjung untuk lebih mudah mendapatkan tujuannya.

Berdasarkan hasil analisis untuk keempat variabel penelitian dapat dibandingkan kelayakan ketiga taman berdasarkan karakteristik fisiknya seperti di Tabel 1 berikut.

Tabel 1. Perbandingan kelayakan Taman Kota Gajahwong berdasarkan karakteristik fisik

\begin{tabular}{|c|c|c|c|}
\hline Variabel & Taman GEP & Taman Wifi & Taman Krida \\
\hline $\begin{array}{l}\text { Kemenarikan } \\
\text { taman }\end{array}$ & $\begin{array}{l}\text { Memiliki kemenarikan taman } \\
\text { yang paling layak karena } \\
\text { memiliki ketersediaan } \\
\text { fasilitas paling lengkap, } \\
\text { desain taman yang menarik } \\
\text { dan beragam fungsi } \\
\text { (ekologis, sosial, rekreasi, } \\
\text { dan edukasi), tamannya } \\
\text { paling luas }\end{array}$ & $\begin{array}{l}\text { Memiliki } \\
\text { kemenarikan taman } \\
\text { cukup karena } \\
\text { meskipun } \\
\text { ketersediaan fasilitas } \\
\text { penunjang paling } \\
\text { namun fungsi taman } \\
\text { kurang beragam } \\
\text { hanya untuk fungsi } \\
\text { sosial dan rekreasi. }\end{array}$ & $\begin{array}{l}\text { Memiliki kemenarikan taman } \\
\text { kurang layak karena minim } \\
\text { fasilitas dan hanya terdapat } \\
\text { fasilitas olahraga yang } \\
\text { terbatas penggunaannya }\end{array}$ \\
\hline $\begin{array}{l}\text { Elemen/ } \\
\text { infrastruktur } \\
\text { pendukung }\end{array}$ & Sudah terdapat peta taman & $\begin{array}{l}\text { Belum terdapat peta } \\
\text { taman }\end{array}$ & Belum terdapat peta taman \\
\hline $\begin{array}{l}\text { Penataan } \\
\text { vegetasi }\end{array}$ & $\begin{array}{l}\text { Vegetasi rimbun karena } \\
\text { banyak pepohonan besar } \\
\text { sehingga digunakan untuk } \\
\text { hidup berbagai flora dan } \\
\text { fauna dan tertata karena } \\
\text { dikelola oleh DLH Kota } \\
\text { Yogyakarta }\end{array}$ & $\begin{array}{l}\text { Vegetasi } r \text { cukup } \\
\text { karena tidak terlalu } \\
\text { banyak pepohonan } \\
\text { dan sifat vegetasi } \\
\text { didominasi berupa } \\
\text { tanaman hias }\end{array}$ & $\begin{array}{l}\text { Vegetasi cukup karena tidak } \\
\text { terlalu banyak pepohonan }\end{array}$ \\
\hline Aksesibilitas & $\begin{array}{l}\text { Lokasi taman strategis } \\
\text { karena sudah terlebih dahulu } \\
\text { dikenal khalayak umum dan } \\
\text { dilengkapi papan petunjuk } \\
\text { arah menuju taman di pintu } \\
\text { masuk Kampung Gambiran }\end{array}$ & $\begin{array}{l}\text { Lokasi taman cukup } \\
\text { strategis karena } \\
\text { dekat jalan masuk } \\
\text { taman sehingga } \\
\text { terlihat dari jalan }\end{array}$ & $\begin{array}{l}\text { Lokasi taman tidak strategis } \\
\text { karena berada di dalam gang } \\
\text { dan belum terdapat papan } \\
\text { petunjuk arah menuju taman }\end{array}$ \\
\hline
\end{tabular}


Penelitian menunjukkan bahwa dari ketiga taman yang berada di kawasan Taman Kota Gajahwong, Gajahwong Educational Park (Taman GEP) adalah taman yang paling layak dan menarik untuk dikategorikan sebagai RTH publik. Ini karena Taman GEP memiliki keunggulan dari segi luasan taman, aksesbilitas maupun fasilitas yang lengkap. Taman GEP juga mampu menampung berbagai macam aktivitas, baik sebagai ruang sosial, rekreasi dan olahraga, ekologis, dan edukasi. Sedangkan Taman Wifi merupakan taman yang paling baru dibangun dibandingkan kedua taman lainnya sehingga dari segi kondisi, taman ini masih baik. Beberapa daya tarik yang dimiliki Taman Wifi, seperti kolam ikan, air terjun mini kursi taman, dan fasilitas free hotspot area menjadi daya tarik tersendiri. Namun demikian, jika dilihat dari fungsinya, Taman Wifi kurang begitu beragam karena lebih diperuntukkan untuk menunjang fungsi sosial dan rekreasi. Sedangkan Taman Krida menjadi taman yang dianggap kurang layak dan tidak menarik karena hanya terdapat fasilitas olahraga yang kurang mempunyai daya tarik sendiri atau terbatas penggunaannya. Selain itu, keberadaan taman tersebut juga kurang diketahui pengunjung dan hanya dimanfaatkan oleh masyarakat sekitar karena lokasi yang kurang strategis berada di dalam gang. Beberapa temuan ini mengkonfirmasi penelitianpenelitian sebelumnya bahwa karakteristik fisik ruang akan mempengaruhi daya tarik kunjungan, seperti temuan Bandaso \& Widjajanti (2019) yang lebih menekankan pada kondisi aksesibilitas taman, ketersediaan fasilitas penunjang dan kondisi kebersihan taman (Imansari \& Khadiyanta, 2015; Pratomo et al., 2019). Karakteristik fisik taman memberikan kenyamanan tersendiri bagi penggunanya karena suasana yang ditimbulkan dan fungsi ruang yang dapat diciptakan oleh taman tersebut (Noor et al., 2018).

\section{Kesimpulan}

Secara umum, ketiga taman kota yang berada di Kawasan Taman Kota Gajahwong terkategori layak sebagai taman kota karena memiliki kondisi fisik taman, elemen pendukung, aksesibililitas, dan keberadaan vegetasi dengan kondisi layak hingga cukup layak. Jika dibandingkan antara ketiga taman, Gajahwong Educational Park (Taman GEP) merupakan taman yang sangat menarik karena dilengkapi dengan berbagai fasilitas didalamnya seperti permainan anak-anak, gazebo, papan informasi, petunjuk arah, dan berbagai fasilitas lainnya. Gajahwong Educational Park layak untuk dijadikan model pengembangan taman kota di Kota Yogyakarta yang menekankan pada aspek kelengkapan fasilitas penunjang, aksesibilitas, dan fungsi taman yang dapat digunakan untuk menampung beragam aktivitas. Sedangkan, Taman Krida dikatakan kurang menarik karena hanya terdapat fasilitas olahraga di dalamnya dan, petunjuk arah yang belum ada, dan lokasi yang kurang strategis.

\section{Referensi}

Bandaso, A., \& Widjajanti, R. (2019). Pengaruh Kondisi Tatanan Fisik Terhadap Kenyamanan Pengunjung Pada Taman Vatulemo di Kota Palu. Tataloka, 21(2), 348. https://doi.org/10.14710/tataloka.21.2.348-360

Budiyanti, R. B. (2013). Manfaat Taman Kota sebagai Rona Kegiatan Publik bagi Masyarakat di Kota Jakarta. Institut Teknologi Bandung.

Carr, S. (1992). Public Space. Cambridge University Press.

Danisworo, M. (1992). Teori Perancangan Urban. Program Studi Perancangan Arsitektur Pasca Sarjana ITB.

Hakim, R. (2003). Unsur Perencanaan dalam Arsitektur Lansekap. Bina Aksara.

Hariyadi, F., Widyastuti, D., \& Joni Purwohandoyo. (2015). Identifikasi Kualitas Fisik Taman Kota Sebagai Ruang Terbuka Publik (Kasus: Bagian Wilayah Kota I, II, III Kota Semarang). Jurnal Bumi Indonesia, 4(3), 1-14.

Harjanti, I. M., \& Anggraini, P. (2020). Green Open Space Functions in Kauman Area, Semarang City, Indonesia. Journal of Architectural Design and Urbanism, 3(1), 1-9. https://doi.org/10.14710/jadu.v3i1.7164

Imansari, N., \& Khadiyanta, P. (2015). Penyediaan Hutan Kota dan Taman Kota sebagai Ruang Terbuka Hijau (RTH) Publik Menurut Preferensi Masyarakat di Kawasan Pusat Kota Tangerang. Ruang, 1(3), 101-110. https://doi.org/10.14710/ruang.1.3.101-110

Keputusan Menteri Dalam Negeri No. 1 Tahun 2007 tentang Penataan RTH Kawasan Perkotaan.

Lynch, K. (1960). The Image of the City. The MIT Press. 
Mandagi, A. G. U. (2013). Perencanaan Taman Edukasi Lingkungan untuk Anak-Anak di Situ Cikaret, Kecamatan Cibinong, Kabupaten Bogor. Institut Pertanian Bogor.

Mashuri, M., Inrianingrum, L., \& Diharto, D. (2012). Identifikasi Ruang Terbuka Hijau Publik Kota Rembang. Teknik Sipil \& Perencanaan, 14(1), 21-28. https://doi.org/10.15294/jtsp.v14i1.7101

Nasution, A. D., \& Zahrah, W. (2014). Community Perception on Public Open Space and Quality of Life in Medan, Indonesia. Procedia - Social and Behavioral Sciences, 153, 585-594. https://doi.org/10.1016/j.sbspro.2014.10.091

Noor, A., Winandari, M. I. R., \& Ischak, M. (2018). Karakter Pengguna Ruang Publik Di Taman Ayodya Jakarta Selatan. Jurnal Penelitian Dan Karya Ilmiah Arsitektur Usakti, 16(02), 60. https://doi.org/10.25105/agora.v16i02.3229

Peraturan Menteri Pekerjaan Umum No 05/PRT/M/2008 Tentang Pedoman Penyediaan dan Pemanfaatan Ruang Terbuka Hijau di Kawasan Perkotaan.

Pratomo, A., Soedwiwahjono, S., \& Miladan, N. (2019). Kualitas Taman Kota Sebagai Ruang Publik di Kota Surakarta Berdasarkan Persepsi dan Preferensi Pengguna. Desa-Kota, 1(1), 84-95. https://doi.org/10.20961/desa-kota.v1i1.12494.84-95

Setyaningrum, D., \& Susanti, R. (2019). Kajian Daya Tarik Ruang Terbuka Hijau Publik di Kampung Hijau Gambiran, Kota Yogyakarta. Teknik PWK (Perencanaan Wilayah Kota), 8(4), 180-188.

Shakia, N. F., Sasongko, W., \& Setyono, D. A. (2020). Rekomendasi Penyediaan RTH Publik Aktif di Kecamatan Kepanjen Berdasarkan Persepsi Masyarakat. Jurnal Tata Kota Dan Daerah, 12(2), 7182.

Shirvani, H. (1985). The Urban Design Process. Van Nostrand Reinbold.

SNI-03-1733-2004 tentang Tata Cara Perencanaan Lingkungan Perumahan Perkotaan

Susiloarifin, H., \& Nurhayati. (1994). Pemeliharaan Taman. Penebar Swadaya.

Yogyakarta, D. L. H. K. (2019). RTHP Taman Wifi Gajahwong.

Undang-undang No. 26 Tahun 2007 tentang Penataan Ruang.

Undang-undang No. 28 Tahun 2002 tentang Bangunan Gedung. 